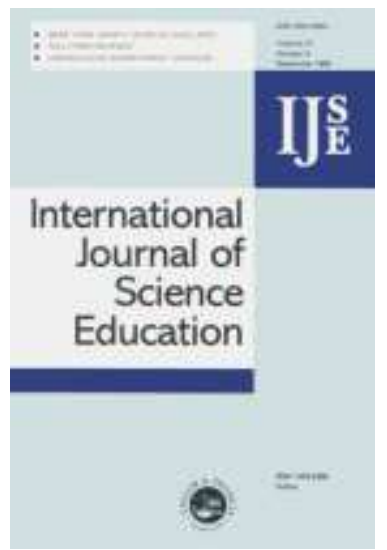

\title{
Is judgement of biotechnological ethical aspects related to high school students' knowledge?
}

\begin{tabular}{|r|l|}
\hline Journal: & International Journal of Science Education \\
\hline Manuscript ID: & TSED-2010-0419-A.R1 \\
\hline Manuscript Type: & Research Paper \\
\hline Keywords : & argumentation, biotechnology education, ethics \\
\hline Keywords (user): & high school education \\
\hline & \\
\end{tabular}

\section{SCHOLARONE ${ }^{\text {TM }}$ Manuscripts}




\title{
Is judgement of biotechnological ethical aspects related to high school students'
}

\section{knowledge?}

\begin{abstract}
Quantitative and qualitative studies of various aspects of the perception of biotechnology were conducted among 469 Slovenian high school students of average age 17 years. Our research aimed to explore relationships among students' pre-knowledge of molecular- and human genetics, and their attitudes to four specific biotechnological applications. These applications - Bt corn, genetically modified salmon, somatic- and germ line gene therapy were investigated from the viewpoints of usefulness, moral acceptance and risk perception. In addition, patterns and quality of moral reasoning related to the biotechnological applications from the aspect of moral acceptability were examined. Clear gender differences were found regarding the relationship between our students' pre-knowledge of genetics and their attitudes to biotechnological applications. While females with a better genetics background expressed a higher risk perception in the case of genetically modified salmon, their similarly welleducated male colleagues emphasized risk associated with the use of germ line gene therapy. With all four biotechnological applications, patterns of both rationalistic - deontological and teleological - and intuitive moral reasoning were identified. Students with poorer genetics pre-knowledge applied an intuitive pattern of moral reasoning more frequently than their peers with better pre-knowledge. A pattern of emotive reasoning was detected only in the case of genetically modified salmon. A relatively low quality of students' moral reasoning, as demonstrated by their brief and small number of supporting justifications (explanations), show that there is a strong need for practising skills of argumentation about socio-scientific issues in Slovenian high schools on a much larger scale. The implications for future research
\end{abstract}


and classroom applications are discussed.

\section{Introduction}

Over recent decades, biotechnology has made tremendous development and is now offering a new generation of unprecedented products and services to society. Modern biotechnology, including gene technology, has been increasingly applied in healthcare and in a number of industrial and agricultural industries. Due to the potential benefits as well as the risks that it poses to our society, an assessment of the public perception of these issues, especially among young people who will have to make decisions related to the use of biotechnology products in the near future, is vital. We have already published an article about Slovene students' attitudes in relation to four different biotechnological applications - Bt corn, genetically modified (GM) salmon, somatic- and germ line gene therapy (GT) - from the viewpoints of usefulness, moral acceptance and risk perception (Črne-Hladnik, Peklaj, Košmelj, Hladnik, \& Javornik, 2009). In the present paper, we have focused on ethical aspects of the perception of gene technology and on the relationship between students' pre-knowledge and their moral reasoning.

\section{Ethics of biotechnological applications and moral reasoning}

Ethics seeks to find reasoned, consistent and defensible solutions to moral problems. Bioethics, a subsection of ethics, uses ethical principles and decision making to solve actual or anticipated dilemmas in medicine, biology and biotechnology. Since biotechnology raises numerous ethical questions, various science educators (Pedretti, 1999; Zeidler, 1984) suggest that, when dealing with issues such as genetic engineering, a consideration of morality and ethics must be taken into account. In our study, four biotechnological examples - Bt corn, 
GM salmon and somatic- and germ line GT - were investigated. Each of them involves bioethical dilemmas that can be characterized by one or more of the following features:

- Good reasons are proposed both for supporting and for opposing a particular course of action;

The ethical acceptability of a course of action depends to a significant degree on scientific evidence, which may be complex and/or incomplete and/or debatable;

- A decision has to be made by, and/or for, society as a whole, in which a significant number of people may oppose the opinion held by most scientific experts" (Mepham, 2005: p. 45).

Biotechnological practices, such as cloning, stem cells, GT, GM food and environmental challenges - e.g. global change - are referred to as socio-scientific issues (SSI). They differ from other issues in science in that they are open-ended, ill-structured, debatable problems subject to multiple perspectives in finding solutions (Kuhn, 1991; Means \& Voss, 1996). Recent conceptualization of SSI education distinguishes it from previous approaches, such as the Science - Technology - Society (STS) movement. While the STS curriculum typically stresses the impact of decisions in science and technology on society, it does not deal explicitly with the ethical issues contained within choices about means and ends, nor does it consider the moral or character development of students (Zeidler et al., 2005). According to Zeidler et al. (2002), "SSI is a broader term that subsumes all that STS has to offer, while also considering the ethical dimensions of science, the moral reasoning of the child, and the emotional development of the student" (p. 344). Fowler et al. (2009) investigated how teaching a year-long curriculum using SSI affects the development of students' moral sensitivity. The curriculum for the experimental (treatment) group included multiple activities that required participants to evaluate claims, analyse evidence and sources, and make moral decisions for a particular genetic modification scenario. Although both the experimental and 
the comparison groups showed an increase in moral sensitivity, the increase in the case of the former was significantly higher than with the latter.

Although often used interchangeably, there are some subtle but important differences between the terms informal and moral reasoning. Some scholars argue that moral reasoning is an integral part of informal reasoning (Andrew \& Robottom, 2001; Solomon, 1994). Means and Voss (1996) provided an illustrative description: "Informal reasoning assumes importance when information is less accessible, or when the problems are more open-ended, debatable, complex, or ill-structured, and especially when the issue requires that the individual build an argument to support a claim" (p. 140). Bioethicists have linked issues associated with genetic engineering to moral reasoning (Evans, 2002; Haker \& Beyleveld, 2000; Stock \& Campbell, 2000). They see it as the process of determining right or wrong in a given situation. Ethical theories and principles are the foundations of ethical analysis because they are the veiwpoint from which guidance can be obtained along the pathway to a decision. Much of applied ethics is concerned with three ethical theories that philosophers have proposed with the aim of systematizing, and hence facilitating, ethical decision-making:

- "The ethical approach called consequentialism is the view that our actions should be ethically determined by the consequences likely to result from them. The desired consequences clearly need to be specified to make this a useful theory and, in the most prominent form of consequentialism, called utilitarianism, the aim is to "produce the greatest good for the greatest number". This theory was introduced by Jeremy Bentham in the $18^{\text {th }}$ century and was further developed by John Stuart Mill (1806-1873)" (Mepham, 2005: p. 31). - "The deontological theory refers to the rights and duties we have as individuals with respect to other individuals. It is only the intention of an act that is good, not the outcome. The theory had its origins in the ideas of the philosopher Immanuel Kant (1724-1804)". 
"The virtue theory, derived from Aristotle's and Confucius's notions, puts emphasis on

the pearson who performs the actions and makes the choices, rather than on the situations in which choices have to be made" (Mepham, 2005: p. 34).

Some investigators (e.g. Andrew \& Robottom, 2001; Zeidler et al., 2002) have argued that SSI, by definition, involve morality, and various studies have been performed that support this claim. Sadler and Zeidler (2004) conducted interviews with students from a public university in the southeastern United States. The interviewer asked explicit questions regarding students' feelings and reactions to GT and cloning and the role of moral or ethical considerations in their decision-making. The research questions were: To what extent do students construe genetic engineering issues as moral problems? and How do moral considerations influence construal and resolution of genetic engineering issues? Qualitative analysis of the interview transcripts showed that, in most cases, students construed the issues as moral problems and demonstrated decision-making patterns consistent with moral construal. The emergent moral-based patterns of decision-making included moral reasoning based on consequences or principles, moral emotion-based choice, and moral intuitionism. The first pattern - also called rationalistic - describes reason-based considerations. In the case of moral emotion-based choice, students did not base their judgements on rational deliberations of consequences or principles; they rather expressed them as an unfavorable or favorable emotion, such as empathy and sympathy (Hoffman, 2000). Indiviudals who showed emotive reasoning seemed genuinely to care about the well-being of others. Ethical intuitionism, on the other hand, means that students did not support these resolutions with an analysis of consequences, principles, emotions, or any other discernible factors: they simply perceived a particular genetic engineering application as morally right or wrong. Intuitive informal reasoning describes considerations based on immediate reactions to the context (Sadler \& Zeidler, 2004). 
Reiss (2008) reported on the use of ethical frameworks by 16-18-year old students following an advanced biology course. The course was taught through contexts and had a strong emphasis on social aspects of biology and ethical analysis of biological issues. Examination of a sample of reports on the topic of global warming written by students showed that utilitarian ethical reasoning - maximising the amount of good in the world - was used widely and that other ethical frameworks to which students were introduced in the course - rights and duties, autonomy and virtue ethics - were used substantially less often. That the prevailing ethical framework always depends on the context, i.e., on the nature of the investigated topic, was shown by Dawson and Taylor (2000), who came to different conclusions in their study. They surveyed 15-year old science students after they had undertaken a transplantation technology course. Students were asked to respond to a series of bioethical dilemmas, determine an outcome, and justify their reasons using the four bioethical principles of autonomy ("the right to choose"), justice (fairness), beneficence (promoting good), and non-maleficence (avoidance of harm). The focus of that paper was to compare the moral reasoning of students to that of three experts. The students' justification of their decisions seemed to be based largely on the bioethical principle of autonomy. In contrast, the responses and reasons stated by the experts seemed to indicate that, in addition to autonomy, they also considered the principles of non-maleficence, justice, and beneficence. The students did not appear to be able to extrapolate the long-term consequences of their decisions.

In his survey, Sjöberg (2004) investigated attitudes to ten specific applications of gene technology among the general population in Sweden; the age distribution of participants was fairly similar to national statistics. Moral aspects emerged as the most important ones. However, different kinds of gene technology were assessed in different ways in terms of morality. The use of gene technology in the food industry was judged to be morally less acceptable than for medical use, and changing the genes of plants was more acceptable than 


\section{Relationship between students' knowledge and their attitudes to biotechnology and informal reasoning}

The relationship between genetics knowledge and attitude to biotechnology is fairly complex. Klop and Severiens (2007) found in a cluster analysis-based study that only a small subset (22\%) of students with the highest level of content knowledge were also highly positive about the attributes of biotechnology. They were referred to as "confident supporters of biotechnology in their daily life". Some studies have shown that people with a sound knowledge base find it easier to express a decided view, irrespective of whether they are positive or negative about issues related to gene technology (Jallinoja \& Aro, 2000). Sadler and Zeidler (2005) examined the effects of genetics knowledge on the patterns and quality of informal reasoning about genetic engineering issues. Participants with more advanced understanding of genetics demonstrated fewer instances of reasoning flaws, i.e. a better 
reasoning quality as defined by a priori criteria, and were more likely to incorporate knowledge in their reasoning patterns than participants with a more naive understanding of genetics. On the other hand, data obtained from interviews produced no noticeable qualitative patterns that distinguished individuals with high levels of genetics knowledge from those with relatively low levels of genetics knowledge in terms of the reasoning patterns (i.e. rationalistic, emotive, and intuitive informal reasoning). According to this research, it can be suggested that educators who use socioscientific curricula, particularly materials related to genetic engineering, need to maintain a critical awareness of their students' content knowledge. Chang and Chiu (2008) conducted a survey that dealt only partly with biotechnological issues, and similarly found that science majors showed better argumentation skills than non-science majors and that background knowledge was related to the ability of argumentation.

\section{Research questions}

In the present paper, the knowledge of the molecular and human biology, and the complexity of ethical dilemmas on the assessment of four different biotechnological applications $-\mathrm{Bt}$ corn, GM salmon, somatic- and germ line GT - from the viewpoints of usefulness, moral acceptance and risk perception are investigated. In addition, the patterns and quality of moral reasoning about the four biotechnological examples are discussed. In our study, the following three research questions were formulated:

1. How does the assessment of four biotechnological applications correlate with preknowledge of molecular and human genetics?

2. What kind of patterns of moral reasoning can we expect about the biotechnological applications from the viewpoint of moral acceptability? Is there any relationship between preknowledge and patterns of moral reasoning? 


\section{Methods and procedures}

In this section, we describe the participants and the administration of the study, the development of the instruments, the data collection process and the analytical procedure.

\section{Participants and administration}

A total of 469 students (299 females and 170 males) from eight general secondary schools from various Slovenian regions participated in the study, which was conducted over the course of one school year. The study was carried out in the third class, after the students, aged 17 in general, had been taught the fundamentals of molecular and human genetics. We first tested the students to obtain an overview of their pre-knowledge on these topics (see subsection Development of the instrument for assessing the pre-knowledge of genetics).

Since the assessment of biotechnological applications always depends on the particular case, we selected four different applications - two from the fields of agriculture and food production and two from medicine. Several science educators (Pedretti, 1999; Sadler \& Zeidler, 2004) have reported in studies that some participants cited a lack of knowledge about genetics as a factor contributing to their inabilitiy to discuss genetic engineering issues. To avoid this potential problem, the above mentioned applications were presented to our students using MS PowerPoint (Table 1) and three excerpts from two documentary films - DNA: Promise and Price (Discovery Channel, 2002) and "Harvest of Fear" (Frontline and Nove coproduction, director Jon Palfreman, 2001) (Table 2). Each excerpt was carefully selected to provide a balanced view of the presented issues, exploring both the potential risks (ecology, health) and the benefits.

Finally, the students individually expressed their opinions on each of the four biotechnological applications from the viewpoints of usefulness, moral acceptance and risk 
perception, by filling out pencil and paper questionnaires (see subsection Ranking difficulty of moral dilemmas accompanying biotechnological applications and assessment of moral reasoning patterns).

\author{
[ Insert Table 1 about here ] \\ [ Insert Table 2 about here ]
}

\title{
Development of the instrument for assessing the pre-knowledge of genetics
}

Since we found no preexisting instruments in the pertinent biology literature that would meet our requirements, we developed a test for use in assessing pre-knowledge and understanding of molecular and human genetics and biotechnology fundamentals. The basic concepts of molecular and human genetics are part of students' regular biology curriculum (20 hours) during the first three years of study. In addition, until very recently, practically no information on biotechnology and genetic engineering issues was presented to secondary school students until their fourth year of study, in which biology is no longer a compulsory subject. In spite of the lack of formal education, we anticipated that the students would have some knowledge about these topics acquired by other means, such as TV, internet and other media. The instrument comprised a total of 24 questions (n) consisting of 17 multiple choice questions with four possible answers and 7 true-false (bivariate) items. Some of them were designed to assess only knowledge, while others addressed also understanding and use of knowledge. The test was previously reviewed by eight secondary school biology teachers and two experts from the field of genetics, for accuracy and clarity with respect to the secondary school level. After the review, several questions/items were modified, improved or omitted. The Cronbach's alpha - coefficient of reliability - for the final instrument was $0.69(n=24)$. 


\section{Ranking difficulty of moral dilemmas accompanying biotechnological applications and assessment of moral reasoning patterns}

Eight experts from the field of natural sciences and seven from social studies were asked to rank the difficulty of ethical dilemmas related to the four biotechnological applications. We wanted in this way to explore whether ethical dilemma difficulty affects the students' judgements of the usefulness of each biotechnological application. A questionnaire and a semi-structured interview were used for this purpose. The experts ranked the applications in decreasing order of moral acceptability as follows: somatic GT, Bt corn, GM salmon and germ line GT.

One of the goals of our study was to investigate the moral reasoning patterns of ethical dilemmas. Similar to the study The Morality of Socioscientific Issues: Construal and Resolution of Genetic Engineering Dilemmas, performed by Sadler and Zeidler (2004), we conducted a qualitative analysis of the arguments given by the students, who were asked to reason their opinion on the moral acceptability of the four biotechnological applications. The question they had to answer was the following: What is your opinion of the moral acceptability of Bt corn production (GM salmon, somatic GT of haemophilia, germ line GT of haemophilia)? Do you find this type of treatment acceptable? Possible responses were: 1 absolutely not, 2 - little, 3 - somewhat, 4 - pretty much 5 - completely. For each biotechnological application, the students supported their opinion by citing one or - rarely several arguments. After reading their arguments, we created several categories (see subsection Statistical and Qualitative Analysis), which belonged to one of the three patterns of moral reasoning: rationalistic (a), emotive (b) and intuitive (c) (Sadler \& Zeidler, 2004):

a) rationalistic moral reasoning is based on either the consequences of the biotechnological applications (teleological reasoning) or moral principles (deontological approach to morality); 
b) moral emotive-based reasoning is characterized by the fact that students do not base their judgements on rational deliberation of consequences or principles, but rather on emotions;

c) in the case of moral intuitive-based reasoning, students respond to the applications intuitively (instinctively), whereby their decisions are not a result of an analysis of consequences, principles or emotions.

As mentioned in the introduction, students also assessed the usefulness and risk perception of the four biotechnological applications. Questionnaires were structured similarly as described above and students reasoned their responses. Since the focus of this paper is on analyzing students' attitudes to the ethical acceptability of biotechnological applications, we only presented questions related to their moral assessment.

\section{Statistical and qualitative analysis}

Spearman's rank correlation coefficient was used to detect possible correlations between the students' pre-knowledge - separately for males and females - and their attitudes towards the four biotechnological applications from the viewpoints of usefulness, moral acceptability and risk perception. The same instrument was applied to determine correlations between the DIT (i.e., P score) and the students' attitudes towards the biotechnological applications.

A general inductive approach was adopted to qualitatively analyse the students' reasoning of the four biotechnological applications from the viewpoint of moral acceptability. Their written argumentations were read, compared with each other and classified into 8 categories. An expert from the field of biotechnology examined $25 \%$ randomly selected questionnaires to evaluate the appropriateness of the methodology. The reliability of evaluation, acquired as a proportion of equally evaluated students' answers by the authors and the expert, exceeded $95 \%$ 
To investigate the relationship between pre-knowledge and the pattern of moral reasoning, two approximately equal groups of students (61 and 56 for low and high knowledge groups, respectively) were created from the total population, based on the results of the genetics pre-knowledge test. In the low knowledge group, the female/male ratio was $36 / 25$, while in the high knowledge group, the ratio was $31 / 25$. We could not obtain genderbalanced groups, since there were $64 \%$ females and $36 \%$ males in the total population. Decisions regarding which scores represented high and low knowledge were made post hoc so that maximum variation subsamples could be obtained. Individuals scoring in the 87th percentile or higher $(18-23)$ comprised the high knowledge group and individuals scoring in the 14th percentile or lower (5 - 9) comprised the low knowledge group.

\section{Results and discussion}

\section{Relationship between the students' pre-knowledge and attitudes towards the biotechnological applications}

The maximum possible score on the genetics pre-knowledge test was 24 , the actual values ranged from 5 to 23 . The mean score for the whole population was 13.77 , with a standard deviation of 3.80 and the scores approximated the normal distribution. Statistical tests comparison of means ( $t$-test; $p=0.67)$ and Mann-Whitney-Wilcoxon test $(p=0.79)$ - showed no statistically significant differences in knowledge between females and males. With respect to the scores achieved, each student was assigned a grade according to the following criteria: $0-49 \%=1,50-62 \%=2,63-75 \%=3,76-89 \%=4$ and $90-100 \%=5$.

Since we wanted to explore whether there are any correlations between the preknowledge test grades and the students' attitudes to the four biotechnological applications from the three viewpoints, the Spearman's rank correlation coefficient (Spearman's rho) test 
statistics was calculated (Table 3). The results showed clear gender differences in some instances. Among females, five statistically significant correlations were found between the pre-knowledge test and their attitudes regarding:

- risk perception of GM salmon $(\mathrm{p}=0.00)$

- usefulness of Bt corn $(\mathrm{p}=0.04)$

- usefulness of GM salmon ( $\mathrm{p}=0.05)$

- usefulness of somatic GT $(\mathrm{p}=0.04)$

- $\quad$ usefulness of germ line GT $(\mathrm{p}=0.04)$

[ Insert Table 3 about here ]

In males, only one such correlation was detected - between the pre-knowledge test and the risk perception of germ line GT ( $\mathrm{p}=0.012)$. It can therefore be concluded that, due to the higher number of significant correlations in females, genetics pre-knowledge here played a more important role than it did with males. Both females and males who had a better genetics background, seemed to exhibit a higher risk perception of two ethically more difficult applications - GM salmon (females) and germ line GT (males). In addition, as shown above, only with females was a weak relationship between genetics pre-knowledge and the usefulness of Bt corn, GM salmon and somatic- and germ line GT was found.

Considering that the focus of our study was predominantly on assessing knowledge and understanding of molecular and human genetics - and only partly actual knowledge from the fields of biotechnology and genetic engineering - our results cannot be directly compared to those obtained from similar studies dealing with correlations between the knowledge of biotechnology and attitudes of individuals to it. In a Dutch study (Klop \& Severiens, 2007), a positive correlation was reported between the knowledge and the attitudes of a group of high- 
school students, so called "confident supporters", who had in common to be very positive about the attributes of biotechnology and, at the same time, expressed the highest level of content knowledge. In the other three groups - "not sure", "concerned sceptic" and "not for me" - however, the level of knowledge could not be related to the students' attitudes. The results of several other studies (Dawson \& Schibeci, 2004; Chen \& Raffan, 1999; Lock et al., 1995) dealing with the relationship between biotechnology knowledge and attitudes were also inconclusive.

\section{Relationship between the difficulty of moral dilemmas related to biotechnological applications ranked by experts and the assessment of their usefulness}

Table 4 summarizes the mean values and standard errors of students' assessments of the four biotechnological applications from the viewpoints of usefulness and moral acceptability as measured using a five-point Likert scale, ranging from 1 -strongly disagree, to 5strongly agree. It was found that both students and experts viewed Bt corn and somatic GT as ethically less problematic in comparison to GM salmon and germ line GT. Germ line GT and GM salmon, both ranked by the experts as ethically more difficult biotechnological applications, were assessed by the students as least useful. On the other hand, students considered somatic GT and Bt corn to be the most useful and the experts as morally the least difficult applications.

[ Insert Table 4 about here ]

\section{Qualitative analysis of moral reasoning patterns}


Results showing categories of rationalistic (deontological and teleological) moral reasoning pattern related to the four biotechnological applications are displayed in Table 5. Numbers indicate how many students cited the particular category; they were allowed to write one or several arguments (justifications) for each application, but most of them named only one or rarely - two. With each of the four applications, another category emerged that could not be included in Table 5, since it does not belong to either rationalistic (deontological or teleological) or emotive or intuitive group of reasoning patterns. This category, referred to as a "two-edged sword", reflects difficulties students faced when they had to assess realistically the benefits and risks related to a particular biotechnological application.

[ Insert Table 5 about here ]

Table 5 contains only those categories that appeared with at least two biotechnological applications. There were two categories specific to Bt corn - "Environmentally friendlier than the use of pesticides" (83) and "Specific action against pests" (29) - one for GM salmon "Animal rights issues" (35) - and also only one for somatic GT - "Last option" (13). As indicated by a very high number of answers designated as "Autonomy of an individual" for somatic GT (136) it can be concluded that the students consider the principle of an individual's autonomy in relation to a decision about a GT procedure to be very important. This widespread opinion among students undoubtedly had a strong influence on their judgement of somatic GT as being ethically the most acceptable of all four biotechnological applications (Črne-Hladnik, Peklaj, Košmelj, Hladnik, \& Javornik, 2009). Dawson and Taylor (2000), who studied bioethical attitudes in the field of human genetics among 14 to 15 years old adolescents (see p. 4), came to similar conclusions. Respect for an individual's autonomy received the highest ranking among the four bioethical principles. 
In comparison to somatic GT, our students viewed Bt corn as morally somewhat less acceptable. This finding can be explained by students' responses in which they expressed concern about the potential negative effects on human health and the environment, while in the case of somatic GT these consequences would be limited to an individual.

Both GM salmon and germ line GT, on the other hand, were much less acceptable applications than the other two. First, students emphasized possible ecological damage as a consequence of the accidental escape of GM salmon into the environment. Second, with respect to germ line GT, students found it morally unacceptable for future parents to decide about the destiny of their children and they were also afraid that the technology might be abused for non-medical purposes.

Sadler and Zeidler (2004) investigated moral acceptability of GT among American students (see p. 5). Although their research methodology differed from ours, some common results as well as differences between the two studies can be highlighted. Both American and our students specified the following teleological arguments: improvement of health (in Table 5: "Benefits"), possible abuse of the method for non-medical use and decrease in variability among individuals. While our students emphasized considerable risk related to germ line GT, American students directly opposed genetic engineering due to its potential to aggravate the problem of overpopulation.

The results of quantitative analysis of intuitive moral reasoning for four biotechnological applications are summarized in Table 6 . The students did not provide any written explanation for their answers; they simply indicated whether they found a particular application morally highly, medium or not at all acceptable. If the students had been interviewed orally, it is possible that they would have explained their opinions or attitudes more extensively.

[ Insert Table 6 about here ] 
As shown in Tables 5 and 6, patterns of both rationalistic - deontological and teleological and intuitive moral reasoning were identified with all four biotechnological applications. Some examples of different patterns regarding the use of Bt corn are presented in Table 7. The data in Table 5 suggested that a majority of students exhibited patterns of rationalistic moral reasoning. In addition, a pattern of emotive reasoning was detected only in the case of GM salmon, with which students expressed concern regarding possible adverse effects on animal health or wellbeing. It is worth mentioning that all emotive reactions were negative and opposed the use of gene technology on animals. We can therefore conclude that of the three patterns of moral reasoning, only emotive pattern was found to be clearly context dependent.

[ Insert Table 7 about here ]

\section{Relationship between pre-knowledge and patterns of moral reasoning}

Table 8 shows a summary of qualitative analysis of moral reasoning for the two groups of students differing in the level their genetics pre-knowledge. The results show that students with a lower knowledge level more frequently applied an intuitive pattern of moral reasoning than their peers who achieved higher grades in the genetics' test. This leads to the conclusion that students with a higher level of genetics knowledge are able to reason their answers better. In addition, students in the high pre-knowledge group seem to be more aware of the difficulty of making a decision when facing a moral dilemma, as indicated by a higher number of "twoedged sword" answers.

[ Insert Table 8 about here ] 


\section{Conclusions}

Modern science education strives to make education more relevant and interesting to students by teaching science in context (Boersma et al., 2007). Since in our study a large majority $98 \%$ - of the participating students returned correctly completed questionnaires, it can be concluded that they were very interested in discussing real-world ethical dilemmas raised by SSI. Another important finding of the study was that the ethical difficulty of the selected biotechnological applications was perceived similarly by the 17-year old students and experts from the fields of natural and social sciences alike. This means that our high school students possess the ability to discuss complex questions related to the use of biotechnology, about which they will soon have to make important decisions, perhaps as voters or in relation to issues regarding their personal health. As stated by Aikenhead (2006) and Levinson (2006), such discussions can help to prepare students for future citizenship. It would also be highly beneficial to incorporate other SSI topics, such as genetic testing, stem cell research, cloning, and global warming into our high school regular biology curricula more often and more extensively. While doing so, however, it is important to make sure that the biology teachers are equipped well enough to teach these controversial topics. By introducing to them some basic bioethical principles they would undoubtedly feel more confident to discuss various moral issues such as those dealt with in our study.

The findings presented in the paper support the notion that the genetics pre-knowledge is related both to the attitudes towards the use of biotechnological applications among adolescents as well as to the patterns of their moral reasoning. A lower level of genetics preknowledge is related to a more frequent appearance of intuitive patterns of moral reasoning, while students with higher levels of genetics pre-knowledge use more rationalistic patterns of 
moral reasoning. We can hypothesize that if some basic scientific background information on biotechnological applications had not been provided to students at the beginning of the study, the number of intuitive and emotive moral reasoning patterns would have probably been higher.

Although the main focus of our study was not on the quality of students' moral reasoning, it should be pointed out that our students mainly explained their attitudes or opinions by providing their own claims, which were supported by one or - rarely - two justifications, i.e. explanations. In the case of students' arguments classified as the intuitive pattern of moral reasoning, only single statements - claims or conclusions - without any justification were presented. Regarding the quantitative and qualitative nature of students' justifications our results are similar to those reported by Sadler and Fowler (2006). They found that US high school students with basic genetic knowledge, when being asked about their attitudes on gene therapy and reproductive cloning, stated on average one or two justifications to support their claims. On the other hand, science major students demonstrated an advanced knowledge and a much better quality of reasoning indicating that a deeper understanding of complex contemporary biological topics leads to a higher quality of reasoning. In our future research we therefore intend to incorporate Slovene science majors to further investigate correlations between the genetics knowledge and students' attitudes towards biotechnological issues.

Another future research topic is the importance of argumentation skills - in addition to that of genetics pre-knowledge - in providing more complex and grounded justifications. Promotion of such skills in a high school practice, however, appears to be a difficult educational task (Sadler, 2004) and requires time and practice. One of the positive steps towards the solution of this problem is a closer cooperation between the teachers of biology on one hand and those of social science subjects, such as sociology, psychology and philosophy, on the other. It could also be helpful to follow the suggestions of Chang and Chin 
(2008) to incorporate in the school practice group discussions and the evaluation process. This could help students thinking about presenting counterarguments and dealing with contradictory evidence. 


\section{References:}

Aikenhead, G. S. (2006). Science Education for Everyday Life - Evidence Based Practice. New York and London: Teachers College Press - Columbia University.

Andrew, J., \& Robottom, I. (2001). Science and ethics: Some issues for education. Science Education, 85, 769-780.

Boersma, K. T., van Graft, M., Harteveld, A., de Hullu, de E., de Knecht-van Eekelen, A., \& Mazereeuw, M. (2007). Leerlijn Biologie van 4 tot 18 jaar. Uitwerking van de concept -contextbenadering tot doelstellingen voor het biologieonderwijs [A learning line for biology for 4 to 18 based on a concept-context approach]. Utrecht: CVBO.

Chang, S., \& Chiu, M.- H. (2008). Lakatos' Scientific Research Programmes as a Framework for Analysing Informal Argumentation about Socio-scientific Issues. Internationa Journal of Science Education, 30(13), 1753-1773.

Chen, S.-Y., \& Raffan J. (1999). Biotechnology: Students' knowledge and attitudes in UK and Taiwan. Journal of Biological Education, 34(1), 17-23.

Črne-Hladnik, H., Peklaj C., Košmelj, K., Hladnik, A., \& Javornik, B. (2009). Assessment of Slovene secondary school students'to biotechnology in terms of usefulness, moral acceptability and risk perception. Public Understanding of science, 18(6), 747-758.

Dawson, V., \& Taylor, P. (2000). Do adolescents' bioethical decisions differ from those of Experts? Journal of Biological Education, 34(4), 184-188.

Dawson, V., \& Schibeci, R. (2003). Western Australian high school students' attitudes towards biotechnology processes. Journal of Biological Education, 38(1), 7-12.

Evans, J. H. (2002). Playing God? Human genetic engineering and the rationalization of public bioethical debate. Chicago, University of Chicago Press. 
Fowler, S. R., Zeidler, D. L., \& Sadler, T. D. (2009). Moral Sensitivity in the Context of Socioscientific Issues in High School Science Students. International Juornal of Science Education, 31(2), 279-296.

Haker, H., \& Beyleveld, D. (2000). The ethics of genetics in human procreation. Adershot, UK, Ashgate.

Hoffman, M. L. (2000). Empathy and moral development: Implications for caring and justice. Cambridge, Cambridge University Press.

Jallinoja, P., \& Aro, A. R. (2000). Does knowledge make a difference? The association between knowledge about genes and attitudes. Journal of Health Communications, 5, 29-39.

Kuhn, D. (1991). The skills of argument. Cambridg: Cambridge University Press.

Klop, T., \& Severiens, S. (2007). An exploration of attitudes towards modern biotechnology: A study among Dutch secondary school students. International Jornal of Science Education, 29(5), 663-679.

Levinson, R. (2006). Towards a theoretical framework for teaching controversial Socioscientific issues. International Journal of science education, 2(10), 1201-1224.

Lock, R., Miles, C., \& Hughes, S. (1995). The Influence of Teaching on Knowledge and Attitudes in Biotechnology and Genetic Engineering Contexts: Implications for Teaching Controversial Issues and the Public Understanding of Science, School Science Review, 76: 47-50.

Means, M. L., \& Voss, J. F. (1996). Who reasons well? Two studies of informal reasoning among children of different grade, ability, and knowledge levels. Cognition and instruction, 14, 139-178.

Mepham, B. (2005). Bioethics an introduction for the biosciences. Universitiy of Nottingham, Oxford University Press. 
Pedretti, E. (1999). Decision making and STS education: Exploring scientific knowledge and social responsibility in schools and science centres through an issues-based approach. School Science and Mathematics, 99, 174-181.

Reiss, M. (2008). The use of ethical frameworks by students following a new science course for 16-18 year-olds. Science \& Education, 17, 889-902.

Sadler, T. D., \& Zeidler, D. L. (2004). The morality of socioscientific issues: Construal and Resolution of Genetic Engineering Dilemmas. Science Education, 88, 4-27.

Sadler, T. D. (2004). Informal Reasoning regarding socioscientific issues: A critical review of research, 41/5, 513-536.

Sadler, T. D., \& Zeidler, D. L. (2005). The significance of content knowledge for informal reasoning regarding socioscientific issues: Applaying Genetics Knowledge to Genetic Engineering Issues. Science Education, 89, 71-93.

Sadler, T. D. \& Fowler, S. R. (2006). A threshold model of content knowledge transfer for socioscientific argumentation. Science Education, 90/6, 986-1004.

Sjöberg, L. (2004). Gene technology in the eyes of the public and experts. Sse/EFI Working Paper Series in Business Administration No. 2004: 7 http://www.hhs.se/SecP/Publications/Electronic.htm (20. mar. 2009)

Solomon, J. (1994). Knowledge, values and public choice of science knowledge. In J. Solomon and G. Aikenhead (Eds.), STS education: International perspectives on reform (pp. 99 - 110). New York: Teachers College Press.

Stock, G., \& Campbell, J. (2000). Engineering the human germline: An exploration of the science and ethics of altering the genes we pass to our children. New York, Oxford Univerity Press.

Zeidler, D. L. (1984). Moral issues and social policy in science education: Closing the literacy gap. Science Education. 68(4), 411-419. 
Zeidler, D. L., Walker, K. A., Ackett, W. A., \& Simmons, M. L. (2002). Tangled up in iews: Beliefs in the nature of science and responses to socioscientific dilemmas. Science Education, 86, 343-367.

Zeidler, D. L., Sadler T. D., Simmons, M. L., \& Howes, E. V. (2005). Beyond STS: A research-based framework for socioscientific issues education. Science Education, 89, $357-377$. 
Table 1. Information presented in the PowerPoint presentations

\begin{tabular}{lll}
\hline Hour & Topic & Content \\
\hline 1 & Gene therapy & Relationship among genes, proteins and genetic traits \\
& What are genetic diseases in general \\
& Purpose and techniques of gene therapy (how to introduce \\
& therapeutic genes into human cells) \\
& Distinction between somatic and germline gene therapy \\
& & Fundamentals of genetic engineering \\
& Genetically modified & Difference between cross breeding and genetic engineering \\
& Production of Bt corn \\
& How to introduce genes into plant cells \\
& Genetically modified & Difference between traditional selection (cross breeding) and \\
animals & genetic engineering \\
& How to introduce genes into animal cells \\
& Main reasons for animal genetic modification (medicine - \\
& onco mouse, genetically modified animals for \\
& xenotransplantation, pharmacology -"biopharming", food \\
& industry - transgenic salmon)
\end{tabular}


Table 2. Information presented in the films

\begin{tabular}{|c|c|c|}
\hline Film & Topic & Content \\
\hline \multirow[t]{4}{*}{1} & Gene therapy & $\begin{array}{l}\text { Information on haemophilia, including causes, symptoms } \\
\text { and treatment }\end{array}$ \\
\hline & & Gene therapy and how it works \\
\hline & & $\begin{array}{l}\text { Successful clinical trial of hemophilia treatment despite } \\
\text { some complications }\end{array}$ \\
\hline & & Some unsuccessful clinical trials of gene therapy \\
\hline \multirow[t]{4}{*}{2} & Bt corn & $\begin{array}{l}\text { Bt corn as an example of genetically modified crop, what it } \\
\text { is, how it works and how to improve control over corn borer } \\
\text { moth }\end{array}$ \\
\hline & & $\begin{array}{l}\text { Ecological and economic benefits when using Bt protein } \\
\text { instead of broad-spectrum insecticides }\end{array}$ \\
\hline & & $\begin{array}{l}\text { Discussion on whether Bt corn pollen represents a significant } \\
\text { risk to monarch butterflies }\end{array}$ \\
\hline & & $\begin{array}{l}\text { Discussion whether the corn borer moth can become } \\
\text { resistant to Bt protein and how to prevent it }\end{array}$ \\
\hline \multirow[t]{2}{*}{3} & $\begin{array}{l}\text { Transgenic salmon } \\
\text { for aquaculture }\end{array}$ & $\begin{array}{l}\text { Creation and farming of transgenic salmon in Atlantic } \\
\text { Canada to increase their growth rate by hormone gene } \\
\text { transfer (economic benefits) }\end{array}$ \\
\hline & & $\begin{array}{l}\text { Concerns raised about the environmental impact of } \\
\text { transgenic fish escaping from a sea cage into the wild and } \\
\text { interacting with the wild salmon (ecological impact); animal } \\
\text { health and welfare (animal rights) }\end{array}$ \\
\hline
\end{tabular}


Table 3. Spearman's correlation coefficient between the genetics pre-knowledge test and the assessment of biotechnological applications, for males and females, from three viewpoints and the corresponding $\mathrm{p}$-value (in parenthesis)

\begin{tabular}{|c|c|c|}
\hline Correlation coefficient ( $p$-value) & $\begin{array}{l}\text { Genetics pre-knowledge test } \\
\quad-\text { males }(\mathrm{n}=134)\end{array}$ & $\begin{array}{c}\text { Genetics pre-knowledge test } \\
\text { - females }(n=256)\end{array}$ \\
\hline Bt corn - Usefulness & $0.09(0.295)$ & $0.13(0.040 *)$ \\
\hline Bt corn - Moral acceptability & $-0.03(0.698)$ & $0.06(0.314)$ \\
\hline Bt corn - Risk perception & $0.13(0.148)$ & $0.10(0.126)$ \\
\hline GM salmon - Usefulness & $-0.04(0.682)$ & $0.12\left(0.046^{*}\right)$ \\
\hline GM salmon - Moral acceptability & $-0.12(0.169)$ & $0.02(0.732)$ \\
\hline GM salmon - Risk perception & $0.08(0.364)$ & $0.24(0.00 * * *)$ \\
\hline Somatic GT - Usefulness & $0.02(0.810)$ & $0.13\left(0.035^{*}\right)$ \\
\hline Somatic GT - Moral acceptability & $0.02(0.781)$ & $0.10(0.111)$ \\
\hline Somatic GT - Risk perception & $0.10(0.255)$ & $0.01(0.933)$ \\
\hline Germ line GT - Usefulness & $-0.03(0.699)$ & $0.13(0.038 *)$ \\
\hline Germ line GT - Moral acceptability & $-0.07(0.424)$ & $0.10(0.124)$ \\
\hline Germ line GT - Risk perception & $0.22(0.012 * *)$ & $0.10(0.121)$ \\
\hline
\end{tabular}

Note: * Statistically significant correlation $(\mathrm{p} \leq 0.05)$.

** Statistically significant correlation $(\mathrm{p} \leq 0.01)$.

$* * *$ Statistically significant correlation $(\mathrm{p} \leq 0.001)$. 
Table 4. Mean values and standard errors for the four studied biotechnological applications from the viewpoints of usefulness and moral acceptability

\begin{tabular}{|c|c|c|c|}
\hline Source & $\mathrm{N}$ & Mean & $95 \%$ conf. intervals \\
\hline \multicolumn{4}{|l|}{ Usefulness } \\
\hline Bt corn & 439 & 3.79 & 0.04 \\
\hline GM salmon & 430 & 3.10 & 0.04 \\
\hline Somatic GT & 443 & 3.73 & 0.04 \\
\hline Germ line GT & 442 & 3.00 & 0.04 \\
\hline \multicolumn{4}{|l|}{ Moral acceptability } \\
\hline Bt corn & 439 & 3.44 & 0.04 \\
\hline GM salmon & 430 & 2.51 & 0.04 \\
\hline Somatic GT & 443 & 3.76 & 0.04 \\
\hline Germ line GT & 442 & 2.60 & 0.04 \\
\hline \multicolumn{4}{|l|}{ Risk perception } \\
\hline Bt corn & 439 & 2.87 & 0.04 \\
\hline GM salmon & 429 & 3.72 & 0.04 \\
\hline Somatic GT & 443 & 3.60 & 0.04 \\
\hline Germ line GT & 440 & 3.71 & 0.04 \\
\hline
\end{tabular}


Table 5. Number of students' answers belonging to different categories of rationalistic deontological and teleological - moral reasoning related to the four biotechnological examples

\begin{tabular}{|c|c|c|c|c|}
\hline & Bt corn & GM salmon & Somatic GT & Germ line GT \\
\hline \multicolumn{5}{|l|}{ Deontological reasoning } \\
\hline Interfering with nature & 71 & 91 & 13 & 64 \\
\hline Autonomy of an individual & & & 136 & 91 \\
\hline No need for genetic modification & 3 & 41 & & \\
\hline \multicolumn{5}{|l|}{ Teleological reasoning } \\
\hline Benefits & 73 & 31 & 108 & 70 \\
\hline Unknown consequences & 112 & 123 & 38 & 73 \\
\hline No harmful effects on descendants & & 3 & 27 & \\
\hline Possible abuse of the method & & & 14 & 57 \\
\hline Progress of science & 13 & 2 & 7 & \\
\hline
\end{tabular}


Table 6. Number of students' answers indicating their intuitive reasoning related to the four biotechnological applications

\begin{tabular}{lcccc}
\hline Intuitive reasoning & Bt corn & GM salmon & Somatic GT & Germ line GT \\
\hline Morally unacceptable & 3 & 26 & 5 & 12 \\
Medium acceptable & 28 & 11 & 6 & 12 \\
Highly acceptable & 46 & 23 & 36 & 14 \\
\hline
\end{tabular}


Table 7. Examples of different patterns of moral reasoning regarding the use of Bt corn

\begin{tabular}{ll}
\hline Pattern & Example \\
\hline Rationalistic-deontological & $\begin{array}{l}\text { "In my opinion, human beings interfere with nature too } \\
\text { frequently and we will sooner or later have to pay for } \\
\text { this. When this happens, it will be too late to take back } \\
\text { genes we once introduced into the living organisms. I } \\
\text { prefer conventional cross breeding to gene technology." } \\
\text { "I find the use of Bt corn acceptable, since it is less } \\
\text { detrimental to the environment than the pesticides." } \\
\text { Rationalistic-teleological }\end{array}$ \\
$\begin{array}{l}\text { Intuitive } \\
\text { Two-edged sword }\end{array}$ & $\begin{array}{l}\text { "The use of Bt corn is more environmental friendly } \\
\text { compared to the pesticides, but can lead to monopoly of } \\
\text { certain producers." }\end{array}$ \\
\hline
\end{tabular}


Table 8. Number of low- and high genetics pre-knowledge individuals exhibiting patterns of informal moral reasoning to four biotechnological applications

\begin{tabular}{lcc}
\hline Pattern & $\begin{array}{c}\text { Low pre- } \\
\text { knowledge }\end{array}$ & $\begin{array}{c}\text { High pre- } \\
\text { knowledge }\end{array}$ \\
\hline Rationalistic deontological & 56 & 76 \\
Rationalistic teleological & 88 & 90 \\
Emotive & 7 & 4 \\
Intuitive & 61 & 28 \\
Two edged sword & 7 & 28 \\
Unclassified & 29 & 22 \\
Total & 248 & 248 \\
\hline
\end{tabular}


Appendix 1: Questionnaire

\section{GENE THERAPY}

\section{Somatic gene therapy for haemophilia}

The presentation and film provided information about somatic gene therapy for haemophilia and some other inherited diseases. Numerous clinical trials are also currently being performed for treating cancer and various contagious diseases, such as AIDS. Somatic gene therapy works by introducing new genes into the body cells of an adult human, whereby these genes will not pass to the next generation, i.e., the offspring.

1. To what extent do you agree with the applicability of somatic gene therapy for haemophilia? Indicate your attitude by marking the appropriate answer number!

$\begin{array}{ccccc}\text { Absolutely not } & \text { Little } & \text { Somewhat } & \text { Pretty much } & \text { Completely } \\ 1 & 2 & 3 & 4 & 5\end{array}$

Briefly explain your decision:

2. What is your opinion of the moral acceptability of somatic gene therapy for haemophilia? Do you consider this type of treatment acceptable?

$\begin{array}{ccccc}\text { Absolutely not } & \text { Little } & \text { Somewhat } & \text { Pretty much } & \text { Completely } \\ 1 & 2 & 3 & 4 & 5\end{array}$

Briefly explain your decision:

3. What is your opinion of the risk associated with somatic gene therapy for haemophilia? Do you consider this type of treatment risky?
Absolutely not
Little
Somewhat
3
Pretty much
4
Completely
5

Briefly explain your decision: 


\section{GENE THERAPY}

Germ line gene therapy for haemophilia

Gene treatment of the above mentioned diseases could also be conducted by introducing new genes into sperms, eggs or at the early stage of embryonic development - so called germ line gene therapy. In this case, the repaired genes would pass to the offspring.

4. To what extent do you agree with the applicability of germ line gene therapy for haemophilia? Indicate your attitude by marking the appropriate answer number!
Absolutely not
1
Little
2
Somewhat
3
Pretty much
4
Completely
5

Briefly explain your decision:

5. What is your opinion of the moral acceptability of germ line gene therapy for haemophilia? Do you consider this type of treatment acceptable?
Absolutely not
Little
2
Somewhat
3
Pretty much
4
Completely
5

Briefly explain your decision:

6. What is your opinion of the risk associated with germ line gene therapy for haemophilia? Do you consider this type of treatment risky?
Absolutely not
1
Little
2
Somewhat
3
Pretty much
4
Completely
5

Briefly explain your decision: 


\section{GENETICALLY MODIFIED PLANTS}

\section{Bt corn}

The presentation and film dealt with the production of Bt corn, a special type of corn that is resistant to corn borer moth. In the following three questions, you should quantify your attitude towards the implications of Bt corn production.

7. To what extent do you agree with the applicability of Bt corn production? Indicate your attitude by marking the appropriate answer number!
Absolutely not
1
Little
2
Somewhat
3
Pretty much
4
Completely 5

Briefly explain your decision:

8. What is your opinion of the moral acceptability of Bt corn production? Do you consider this type of treatment acceptable?
Absolutely not
Little
2
Somewhat
3
Pretty much
4
Completely
5

Briefly explain your decision:

9. What is your opinion of the risk associated with Bt corn production? Do you consider this type of genetic modification risky?
Absolutely not
1
Little
2
Somewhat
3
Pretty much
4
Completely
5

Briefly explain your decision: 


\section{GENETICALLY MODIFIED ANIMALS}

\section{Transgenic salmon}

The presentation and film talked about genetically modified - transgenic - salmon, whose growth rate is on average up to four times higher than that of non-transgenic salmon. In the following three questions you should quantify your attitude towards the implications of genetically modified salmon.

10. To what extent do you agree with the applicability of genetically modified salmon? Indicate your attitude by marking the appropriate answer number!
Absolutely not
Little
Somewhat
3
Pretty much
4
Completely
1
2
5

\section{Briefly explain your decision:}

11. What is your opinion of the moral acceptability of genetically modified salmon? Do you consider this type of treatment acceptable?

$\begin{array}{ccccc}\text { Absolutely not } & \text { Little } & \text { Somewhat } & \text { Pretty much } & \text { Completely } \\ 1 & 2 & 3 & 4 & 5\end{array}$

Briefly explain your decision:

12. What is your opinion of the risk associated with genetically modified salmon? Do you consider this type of genetic modification risky?
Absolutely not
Little
2
Somewhat
Pretty much
4
Completely

Briefly explain your decision: 